\title{
Earnings Management: The Effect of Ex Ante Earnings Expectations
}

\author{
JEFF L. PAYNE* \\ SEAN W. G. ROBB**
}

\begin{abstract}
SEC Chairman Arthur Levitt has recently expressed concerns about the use of earnings management to meet Wall Street earnings expectations set by analysts' forecasts. We investigate whether managers aim to 'meet or beat' analysts' forecasts and examine the influence of analysts' forecast dispersion on this aim. Our results are consistent with managers aligning earnings with market expectations established by analysts' forecasts. Additionally, our evidence is consistent with managers behaving as though they have greater incentives to increase income in settings where the dispersion in analysts' forecasts is low.
\end{abstract}

\section{Introduction}

Anecdotal evidence indicates that there are strong incentives to achieve analysts' earnings forecasts to protect a company's stock price. As mentioned in a Wall Street Journal column, "The rarest commodity in the stock market these days is certainty, and it doesn't come cheap. In the past ... panicky momentum investors have mercilessly pummeled any stocks with the slightest earnings disappointment. There are examples every day of stocks that go down $25 \%$ to $50 \%$ because they missed [analysts'] earnings estimates by a few cents"' (WSJ [1997, pp. C1, C2]). The Securities Exchange Commission (SEC) has noticed this trend, and in a speech at New York University's Center for Law and Business (September 28, 1998), SEC chairman Arthur Levitt noted:

\footnotetext{
*University of Oklahoma

** University of Toronto

We are grateful to Rashad Abdel-khalik, Anwer Ahmed, Mark Anderson, Jennifer Gaver, Jinghong Pierre Lang, Theresa Libby, Partha Sengupta, Morris Stocks, Mark Wilder, and an anonymous reviewer for helpful suggestions. Steve Baginski graciously provided management forecast data. We also thank the participants at the 1996 American Accounting Association Conference, the 1996 Canadian Academic Accounting Association Conference, and workshop participants at the University of Oklahoma, University of Toronto and Wilfrid Laurier University for helpful comments. The authors gratefully acknowledge the contribution of I/B/E/S Inc. for providing earnings per share forecast data, available through the Institutional Brokers Estimate System. I/B/E/S provides these data as part of a broad academic program to encourage earnings expectations research.
} 
Increasingly, I have become concerned that the motivation to meet Wall Street earnings expectations may be overriding common sense business practices. Too many corporate managers, auditors, and analysts are participants in a game of nods and winks. In the zeal to satisfy consensus estimates and project a smooth earnings path, wishful thinking may be winning the day over faithful representation. As a result, I fear that we are witnessing an erosion in the quality of earnings, and therefore, the quality of financial reporting. Managing may be giving way to manipulation; integrity may be losing out to illusion." ... "While the problem of earnings manipulation is not new, it has swelled in a market that is unforgiving of companies that miss their estimates. I recently read of one major U.S. company, that failed to meet its so-called "numbers" by one penny, and lost more than six percent of its stock value in one day.

These remarks by the SEC chairman suggest that managers are concerned about failing to meet earnings expectations set by analysts' forecasts and that "earnings manipulation" is a tool they can use to ensure markets are not disappointed. DeFond and Park (1997) present evidence that indicates managers utilize their discretion to smooth reported income between accounting periods by relying on the earnings expectation set by analysts' forecasts regarding the next period's earnings. ${ }^{1}$ However, this motivation for adjusting reported earnings does not address Chairman Levitt's concerns regarding earnings management (manipulation) to achieve the current analysts' earnings forecast. Chairman Levitt's speculation that managers can manipulate reported earnings is supported by existing research that indicates managers can effectively utilize their discretion to achieve targeted earnings levels. ${ }^{2}$

The purpose of this study is to investigate managers' desire to "meet or beat" the current period's analysts' earnings forecasts. We also investigate managers' incentives to increase reported earnings when the dispersion in analysts' forecasts is low. Our evidence indicates that these motivations are important and influence the magnitude of earnings management. We find that earnings are managed to align with market expectations (as determined by analysts' forecasts). Additionally, when the dispersion in analysts' earnings forecasts is low, managers make greater attempts to "meet or beat" analysts' forecasts and exhibit a consistent desire to increase reported earnings. Our results are robust with respect to model specification and hold up well under tests for alternative incentives to manage earnings.

Our paper makes two contributions to the literature on earnings management. We empirically examine managers' use of their reporting discretion to "meet or

1. DeFond and Park's (1997) findings indicate that managers use their discretion in adjusting reported earnings to increase earnings in the current period when next year's earnings are expected to be "good" and current performance is "bad."

2. Existing research indicates that earnings are managed to avoid debt covenant violations (DeFond and Jiambalvo [1994]), to reduce reported earnings prior to the announcement of a management buyout proposal (Perry and Williams [1994]), and to make income-decreasing reporting decisions during import relief investigations (Jones [1991]). 
beat" analysts' forecasts. We investigate the degree to which ex ante earnings expectations (as measured by analysts' forecasts) influence earnings management. This is in contrast to Matsumoto (1999), where a firm's propensity to avoid negative earnings surprises is facilitated by guiding analysts' forecasts before they are made. We take analysts' forecasts as given and examine the incentives of managers to achieve those forecasts once they are made public. This is a subtle but important difference between our paper and hers. Second, we examine the effect of analysts' forecast dispersion on management's incentives with respect to reported earnings. To date, the degree of analysts' forecast dispersion has not been examined as a possible motivation for earnings management. Our results indicate that both the level and dispersion of analysts' forecasts affect management's financial reporting decisions.

The remainder of this paper is divided into six sections. Section 2 presents the theory and hypotheses to be tested. Section 3 details the data selection criteria and outlines the research design. Sections 4 and 5 present the results and supplemental analyses, respectively. Section 6 presents the conclusions.

\section{Theory and Hypotheses}

Conventional wisdom maintains that analysts' forecasts are a key source of information used by investors when developing expectations of future earnings (Ip [1997]; Fox [1997]). Analysts' forecasts provide input to many of the market's decisions. For example, individual investors consider analysts' forecasts to be among the most influential sources of information for investment decision making (Hirst et al. [1995]), including the determination of future stock prices (Dowen and Bauman [1991]). Managers generally prefer to cooperate with analysts to disseminate earnings information to investors (Ajinkya and Gift [1984]; Lees [1981]). ${ }^{3.4}$ Personal and direct contact with management, along with their assimilation of economic and industry specific components affecting firm value, enables analysts to monitor the credibility of managers' disclosures (King et al. [1990]).

The suitability of using analysts' forecasts as a proxy for market expectations and the costs associated with disappointing the market by failing to meet earnings expectations (i.e., negative stock price reactions) are well established in the accounting literature (e.g., Brown [1993]). The mean of analysts' earnings forecasts is often used as a surrogate for unobservable investor earnings expectations and consistently outperforms other market expectation proxies (e.g., time-series models).

3. Analysts base their forecasts on information obtained from (in order of importance) (1) interviews with management, (2) publicly reported financial statements, (3) annual and quarterly reports, (4) management forecasts (if available), (5) formal presentations by company executives, (6) forecasts by other analysts, and (7) press releases concerning the company (Lees [1981]).

4. Lees (1981) notes many companies make special efforts to assist analysts by preparing factbooks containing statistics on company performance, granting interviews to an individual or groups of analysts, and making presentations at analysts' meetings. 
The extant literature examines many incentives for managers to reduce analysts' forecast errors. Managers fear costly legal actions by shareholders when the market's earnings expectations are not met (Kasznik [1999]; Francis et al. [1995]; Skinner [1994]). These costs are increasing in the magnitude of forecast error (Francis et al. [1995]). Trueman (1986) proposes that managers might use analysts' forecasts as a way to avoid lawsuits arising from earnings that deviate significantly from expectations. He suggests that if investors can infer the actual source of the analysts' forecast information, managers can successfully convey new information about their firm's economic condition to investors through analysts' forecasts. Managers also have incentives to keep bad news, or earnings disappointments, from happening (see Walther and Willis [1999]; Skinner [1994]; Ajinkya and Gift [1984]).

We first examine the setting where premanaged earnings are below analysts' forecasts and subsequently evaluate settings where premanaged earnings are above analysts' forecasts. Premanaged earnings are measured as current period earnings before discretionary accruals. ${ }^{5}$ When premanaged earnings are below analysts' forecasts, management's tenure and reputation (Skinner [1994]; Fama [1980]) ${ }^{6}$ and litigation (Francis et al. [1995]; Skinner [1994]; Trueman [1986]) incentives align to provide a strong desire to avoid an earnings disappointment that leads to reduced credibility and/or potential litigation for failing to update the market with "bad" news. Therefore, managers have incentives to increase income to minimize analysts' forecast error. Stated formally (in alternative form):

$H_{1}$ : When premanaged earnings are below analysts' forecasts, management will increase income to achieve forecasted earnings levels.

We also investigate the degree to which dispersion in ex ante beliefs affects earnings management. Reduced analysts' forecast dispersion implies a high degree of expectation certainty, which in turn both increases the magnitude of investors' responses to unexpected earnings reports (Lipe [1990]) and increases management's incentives to ensure the market is not disappointed (Brown [1993]). Atiase and Bamber (1994) suggest that predisclosure information asymmetry (measured using the dispersion in analysts' forecasts) helps to explain the relationship between volume and price reactions to public disclosures (earnings announcements). A positive relationship between trading volume and dispersion in analysts' forecasts is also found by Ajinkya et al. (1991).

The market reacts differently to different degrees of heterogeneity in analysts' forecasts. Imhoff and Lobo (1992) determine that ex ante uncertainty preceding an earnings announcement impacts the magnitude of the earnings response coefficient (ERC) when earnings are released. Their results indicate that unexpected earnings have a greater effect on unexpected stock price changes as analysts' forecast dis-

5. The estimation of discretionary accruals is discussed in Section 3.

6. Fama (1980) suggests that managers with poor track records or eroded credibility will suffer reduced compensation in efficient labor markets. 
persion declines. Therefore, as earnings forecasts become less disperse, managers potentially have an increased incentive to meet forecasted earnings figures since investors place more value on reported earnings when forecast dispersion is low. ${ }^{7}$ When premanaged earnings are below market expectations, we predict (stated in alternative form):

$H_{2}$ : Management's desire to increase income will be negatively correlated with analysts' forecast dispersion (as dispersion decreases, management will increase income to minimize analysts' forecast error).

An interesting question arises when one considers the behavior of managers in years when premanaged earnings are above analysts' forecasts. If the firm has exceeded market expectations with respect to anticipated earnings, will managers decrease income to achieve analysts' forecasts? Applying Skinner's (1994) asymmetric loss rationale, the incentive to minimize analysts' forecast errors may not apply to settings where premanaged earnings are above analysts' forecasts. When earnings exceed expectations, the market views this as "'good news." This leaves management with conflicting incentives. Management can elect to report higher earnings to increase stock prices now, or reduce reported earnings to the forecasted level. This choice is not related to economic penalties (that do not exist when the market is pleasantly surprised), but rather is a result of the nature of accrual accounting. Accruals that can be managed are not inexhaustible. When a company's earnings exceed market expectations, managers can build up income-increasing accrual "reserves" for use in the future (effectively a rationing policy with respect to the pool of available accruals). Due to conflicting incentives, we leave this issue as an empirical question.

\section{Data and Research Design}

Analyst forecast data are collected from the Institutional Brokers Estimate System $(\mathrm{I} / \mathrm{B} / \mathrm{E} / \mathrm{S}) .^{8}$ The Compustat 1998 database is the source of all earnings and

7. Imhoff and Lobo (1992), Abarbanell et al. (1995), and Barron and Stuerke (1998) present two compelling, yet different, explanations for the negative relationship between investor's reactions to unexpected earnings and analysts' forecast dispersion. Imhoff and Lobo (1992) examine analysts' forecast dispersion preceding earnings announcements and suggest that increased dispersion is reflective of "noise" in the financial statements and does not represent fundamental uncertainty. Abarbanell et al. (1995) provide an alternative explanation. They show that when analysts' forecast dispersion increases (decreases), investors place less (more) reliance on the analysts' forecast estimate and rely more (less) on private information search activities. This in turn leads to decreased (increased) price reactions to subsequent earnings announcements. Barron and Stuerke (1998) find evidence consistent with this proposition, leading them to suggest that the negative relation between ERCs and analysts' forecast dispersion that Imhoff and Lobo report may be consistent with dispersion reflecting uncertainty about a firm's future economic performance. We do not address the cause of the negative relationship that exists between analysts' forecast dispersion and the value relevance of earnings as measured using ERCs (i.e., does analysts' forecast dispersion reflect "noise" in the financial statement generation process or is it reflective of fundamental uncertainty?). For our purposes it is sufficient that prior research indicates that such a relationship exists.

8. We use the mean estimate and standard deviation of analysts' forecasts from the $1 / B / E / S$ 
balance sheet data. We begin by selecting all firms included in the 1998 Compustat Industrial and Full Coverage databases that have analysts' forecast information available from $\mathrm{I} / \mathrm{B} / \mathrm{E} / \mathrm{S}$ for the years 1986-1997. Financial institutions (with SIC codes between 5999 and 7000) are deleted because discretionary accrual estimation is problematic for these firms. Elimination of data for firm-years with missing observations or less than three analysts' forecasts provides an initial sample of 23,986 firm-years. First differencing required during the estimation of discretionary accruals, the elimination of industry/year combinations without a sufficient sample size for portfolio estimation, and removal of extreme observations ${ }^{9}$ reduces the final sample to 13,532 firm-year observations.

\subsection{Estimation of Discretionary Accruals}

Existing studies use numerous methodologies to detect the influence of accounting choices on reported earnings. These include the examination of individual account balances such as bad debt reserves (McNichols and Wilson [1988]) or the choice of specific accounting methods (Sweeney [1994]). Jones (1991) provided the initial insight into the measurement of discretionary or abnormal accruals. Jones's technique estimates normal accruals as a function of the change in revenues and the level of property, plant, and equipment to control for changes in accruals that are due to changes in a firm's economic condition. By subtracting this value from total accruals, an estimate of the discretionary portion of total accruals is possible. The Jones model has been modified to adjust for the change in accounts receivable (Dechow et al. [1995]) and has been applied using both time-series (e.g., Jones [1991]) and cross-sectional (DeFond and Jiambalvo [1994]) estimation techniques.

Earnings management through the discretionary component of accruals is less likely to be visible and therefore is more difficult to infer. Healy (1985) notes that in comparison to voluntary changes in accounting methods (e.g., changing from accelerated to straight-line depreciation), accrual manipulation is a less costly means of transferring earnings between periods. The application of the Jones model allows for estimation of discretionary accruals and controls for changes in accruals that are due to changes in the firm's economic condition.

Consistent with previous studies of earnings management (e.g., Dechow et al. [1995]), total accruals are computed as:

$$
\mathrm{TA}_{t}=\left(\Delta \mathrm{CA}_{t}-\Delta \mathrm{CL}_{t}-\Delta \mathrm{Cash}_{t}+\Delta \mathrm{STD}_{t}-\mathrm{Dep}_{t}\right),
$$

\footnotetext{
History Tape for the month preceding the annual earnings announcement. This improves the accuracy of the aggregated forecast data by focusing on the most recent forecast (O'Brien [1988]). For a forecast observation to be used, at least three analysts must have made a prediction.

9. To be consistent with other studies that examine management's use of discretionary accruals, we exclude highly influential observations using the technique proposed by Besley, Kuh, and Welsch (1980).
} 
where

$\mathrm{TA}=$ total accruals,

$\triangle \mathrm{CA}=$ change in current assets (Compustat item 4),

$\Delta \mathrm{CL}=$ change in current liabilities (Compustat item 5),

$\Delta$ Cash $=$ change in cash and cash equivalents (Compustat item 1),

$\triangle \mathrm{STD}=$ change in debt included in current liabilities (Compustat item 34),

Dep $=$ depreciation and amortization expense (Compustat item 14),

$t=$ time period.

Discretionary accruals are measured applying a cross-sectional variation of the Jones (1991) model, as shown in DeFond and Jiambalvo (1994). Compared to time series based estimation techniques, the industry-level estimation allowed by the cross-sectional approach increases the number of observations used for parameter estimation, controls for industry year variation, and is better specified (Subramanyam 1996). ${ }^{10}$ The time-series approach assumes the parameter estimates are stationary over the time period investigated. This is not a constraint in the cross-sectional model. Our application of the cross-sectional Jones model enables our results to be compared with the existing literature without the constraint of controlling for a different estimation process for discretionary accruals.

The model is applied as

$$
\mathrm{TA}_{i t} / \mathrm{A}_{i t-1}=\alpha_{t}\left(1 / A_{i t-1}\right)+\beta_{1 t}\left(\Delta \operatorname{Rev}_{i t} / A_{i t-1}\right)+\beta_{2 t}\left(\mathrm{PPE}_{i t} / A_{i t-1}\right)+e_{i t},
$$

where

$\mathrm{TA}_{i t}=$ total accruals for sample firm $i$ in year $t$,

$A_{i t-1}=$ total assets for sample firm $i$ in year $t-1$,

$\Delta \operatorname{Rev}_{i t}=$ change in net revenues for sample firm $i$ in year $t$,

$\mathrm{PPE}_{i t}=$ gross property plant and equipment for sample firm $i$ in year $t$,

$e_{i t} \quad=$ error term for sample firm $i$ in year $t$.

Ordinary least squares is used to obtain industry-specific estimates of the coefficients $\left(a_{t}, b_{1 t}\right.$, and $\left.b_{2 t}\right)$ in eq. (2) for each two-digit SIC industry, by year. ${ }^{11}$ The change in revenue is included because changes in working capital accounts (part of total accruals) are affected by changes in revenue. Property, plant and equipment is used to control for the portion of total accruals related to the nondiscretionary depreciation expense. Discretionary accruals (DA) represent the portion of total accruals that are not explained by normal operating activities and are measured as the residual $\left(e_{i t}\right)$ from the above regression.

10. This cross-sectional version of the Jones model has been applied extensively in earnings management research (e.g., DeFond and Jiambalvo [1994]; Subramanyam [1996]; DeFond and Park [1997]; Wu [1997]; Becker et al. [1998]; DeFond and Subramanyam [1998]).

11. We do not use an industry indicator to lighten the notation of the model. 
TABLE 1

\begin{abstract}
Descriptive Statistics for the Sample of Firms Contained in Both the I/B/E/S and Compustat Databases for the Years 1988-1997 Excluding All SIC Codes Between 5999 and 7000, Partitioned by Level of Premanaged Earnings (PME)
\end{abstract}

\begin{tabular}{|c|c|c|c|c|c|c|c|c|}
\hline Variable & Mean & Median & $1 \%$ & $25 \%$ & $75 \%$ & $99 \%$ & $\begin{array}{c}\text { BELOW } \\
\text { PME < } \\
\text { Analysts' } \\
\text { Forecasts }\end{array}$ & $\begin{array}{c}\text { ABOVE } \\
\text { PME > } \\
\text { Analysts' } \\
\text { Forecasts }\end{array}$ \\
\hline$n$ & 13,532 & 13,532 & & & & & 7,704 & 5,828 \\
\hline $\mathrm{TA}_{i t} / \mathrm{A}_{i t-1}$ & -0.034 & -0.041 & -0.256 & -0.075 & 0 & 0.258 & -0.005 & $-0.075^{* *}$ \\
\hline $\mathrm{ROA}_{i t}$ & 0.043 & 0.051 & -0.389 & 0.023 & 0.086 & 0.231 & 0.034 & $0.054^{* *}$ \\
\hline EPS $_{i t}$ & 0.724 & 0.84 & -5.4 & 0.33 & 1.49 & 5.14 & 0.491 & $1.031^{* *}$ \\
\hline $\mathrm{CASH}_{i t} / \mathrm{A}_{i t-1}$ & 0.09 & 0.094 & -0.345 & 0.045 & 0.15 & 0.4 & 0.05 & $0.142 * *$ \\
\hline AFCST $_{i t}$ & 1.048 & 0.93 & -2.19 & 0.46 & 1.56 & 5 & 1.049 & 1.045 \\
\hline $\mathrm{A}_{i r}$ & 2,032 & 614 & 32 & 210 & 2,030 & 17,350 & 2,082 & $1,967^{*}$ \\
\hline $\mathrm{DISP}_{i t}$ & 0.124 & 0.038 & 0 & 0.018 & 0.091 & 1.556 & 0.134 & $0.112^{* *}$ \\
\hline LEVERAGE $_{i t}$ & 0.519 & 0.533 & -0.089 & 0.373 & 0.649 & 1.146 & 0.516 & 0.522 \\
\hline \multicolumn{9}{|c|}{$\begin{array}{l}\text { ** ABOVE significantly different from BELOW at } \mathrm{p}<0.01 \text { (two-tailed } \mathrm{t} \text { test). } \\
\text { * ABOVE significantly different from BELOW at } \mathrm{p}<0.05 \text { (two-tailed } \mathrm{t} \text { test). } \\
\text { able definitions: }\end{array}$} \\
\hline $\begin{array}{l}\text { TA }_{i t} \\
\text { ROA }_{i t} \\
\text { EPS }_{i t} \\
\text { CASH }_{i t} \\
\text { AFCST }_{i t} \\
\text { A }_{i t} \\
\text { DISP }_{i t}\end{array}$ & $\begin{array}{l}=\text { total acc } \\
=\text { EPS } / \text { Tot } \\
=\text { EPS for } \\
=\text { cash flov } \\
=\text { analysts' } \\
=\text { total asse } \\
=\text { measure } \\
\quad \text { forecast }\end{array}$ & $\begin{array}{l}\text { als for sa } \\
\text { assets fo } \\
\text { ample firn } \\
\text { from ope } \\
\text { earnings } f \\
\text { s for sam } \\
\text { of analyst } \\
\text { leasure wa }\end{array}$ & $\begin{array}{l}\text { aple firm } \\
\text { firm } i \text { in } \\
i \text { in year } \\
\text { ations for } \\
\text { recast for } \\
\text { le firm } i \mathrm{f} \\
\text { forecast } \\
\text { available }\end{array}$ & $\begin{array}{l}\text { in year } t \text {. } \\
t \text { ample firm } \\
\text { ample firm } \\
\text { year } t \text { (ir } \\
\text { ispersion } \\
\text { rom } \mathrm{I} / \mathrm{B} / \mathrm{E}\end{array}$ & $\begin{array}{l}i \text { for ye } \\
i \text { for ye } \\
\text { million } \\
\text { calculat } \\
\text { S before }\end{array}$ & $\begin{array}{l}\text { r } t \\
\text { i } t \text {. } \\
\text { of dollar } \\
d \text { in the } \\
\text { he annua }\end{array}$ & $\begin{array}{l}\text { ). } \\
\text { ast month), } \\
\text { earnings anr }\end{array}$ & $\begin{array}{l}\text { summary } \\
\text { uncement. }\end{array}$ \\
\hline
\end{tabular}

\title{
4. Results
}

The descriptive statistics for sample firms reported in Table 1 indicate that firms with premanaged earnings below analysts' forecasts (BELOW firms) generally report lower levels of return on assets, earnings per share, and cash flows from operations than ABOVE firms. In addition, these firms are slightly larger and have more dispersion in analysts' forecasts when compared to firms with premanaged earnings above analysts' forecasts (ABOVE firms). The significant differences in cash flows from operations (CASH) and operating performance (ROA and EPS) are of concern. The CASH (Shivakumar [1996]) and relative level of operating performance variables (Dechow et al. [1995]) have been shown to affect the estimation of discretionary accruals. Accordingly, these differences are controlled for in our subsequent analysis. There is no significant difference in the level of the 
TABLE 2

\section{Analysis of Discretionary Accruals \\ Based on the Level of Premanaged \\ Earnings Compared to \\ Analysts' Forecasts}

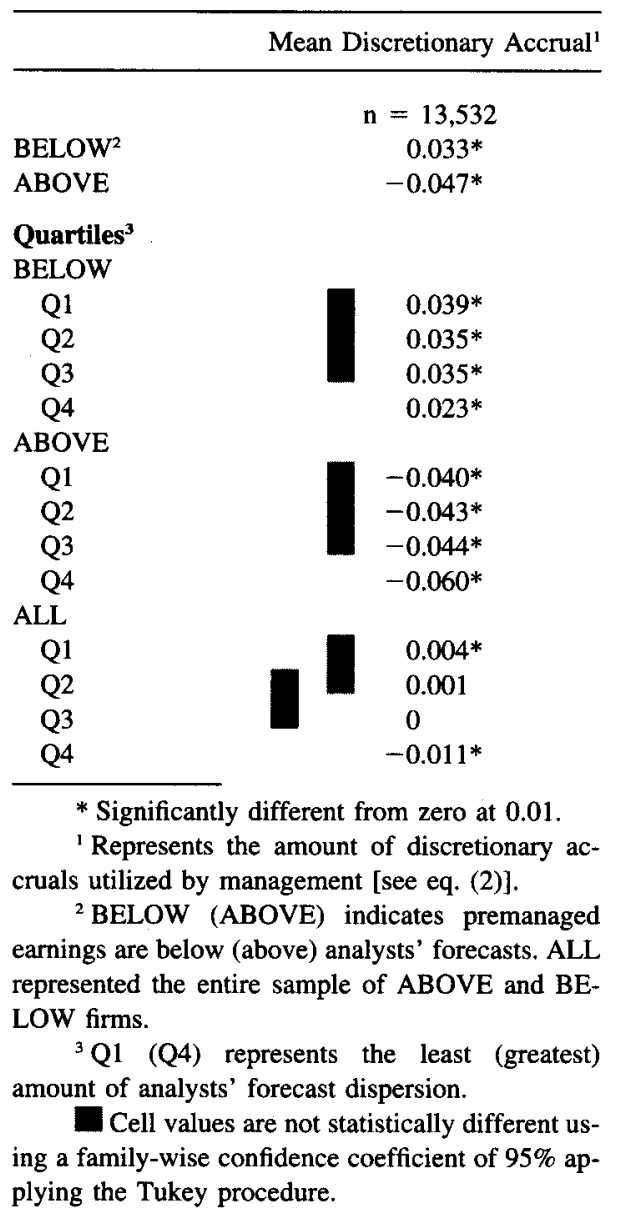

mean analysts' forecast or financial leverage between the BELOW and ABOVE groups.

\subsection{Univariate Test of Hypotheses}

Mean levels of discretionary accruals are reported in Table 2 for the total sample based on the level of premanaged earnings (above or below the analysts' 
forecast). We hypothesize that when premanaged earnings are below analysts' forecasts, discretionary accruals will be positive. We test this by determining if mean discretionary accruals are significantly positive. The results in Table 2 indicate strong support for $H_{1}$. When premanaged earnings are below analysts' forecasts, discretionary accruals are significantly positive $(B E L O W=0.033)$. We also find that when premanaged earnings are above analysts' forecasts, discretionary accruals are significantly negative (ABOVE $=-0.047$ ).

To determine if managers' use of discretionary accruals is affected by the degree of analysts' forecast dispersion, a dispersion variable (DISP) is calculated, ex post, to measure the variation in analysts' forecasts. DISP is calculated for the month preceding the annual earnings announcement for each firm-year as the standard deviation across analysts' forecasts divided by the absolute value of the mean EPS forecast during the month. This standardization renders DISP scale-free across firms and is similarly defined in Comiskey et al. (1987), Elliott and Philbrick (1990), and Ajinkya et al. (1991). ${ }^{12}$ If analysts' forecast dispersion affects managers' use of income-increasing discretionary accruals, as predicted in $H_{2}$, we expect $\mathrm{Q} 1>\mathrm{Q} 2>\mathrm{Q} 3>\mathrm{Q} 4$ (where Q1 [Q4] represents the estimated mean discretionary accrual value for the quartile of companies with the lowest [greatest] analysts' forecast dispersion) for BELOW firms. The Tukey procedure (Neter, Wasserman, and Kutner 1985) applied with a family confidence coefficient of 95 percent for BELOW firms indicates that Q1 $=\mathrm{Q} 2=\mathrm{Q} 3>\mathrm{Q} 4$ supporting $H_{2}$. For $\mathrm{ABOVE}$ firms, $\mathrm{Q} 1=\mathrm{Q} 2=\mathrm{Q} 3>\mathrm{Q} 4$. The analysis of firms without the ABOVE/ BELOW dichotomy indicates that $\mathrm{Q} 1>\mathrm{Q} 3>\mathrm{Q} 4$ and $\mathrm{Q} 2>\mathrm{Q} 4$. Overall, this analysis indicates that as analysts move toward agreement regarding expected earnings (as evidenced by reduced analysts' forecast dispersion) managers consistently use discretionary accruals to increase reported earnings.

\subsection{Multivariate Test of Hypotheses}

To examine the robustness of our results with respect to incentives to manage earnings other than to meet analysts' forecasts, OLS estimates were obtained from the following regression: ${ }^{13}$

12. If both the timing of forecast updates and the information available to analysts in making their updates varies across analysts, then differences in EPS estimates will be due in part to differential information available to analysts at different times. This will add noise to the DISP measure and make it more difficult to support our hypotheses.

13. The summary $\mathrm{I} / \mathrm{B} / \mathrm{E} / \mathrm{S}$ forecast measures from the History Tapes have been called into question in settings investigating forecast revision after earnings announcements (Barron and Stuerke [1998]). We investigate earnings management before the earnings announcement. However, to ensure the robustness of our results additional analyses were performed using analysts' forecast information from the fourth fiscal quarter (I/B/E/S History Tapes), the last earnings forecast from an individual analyst before the annual earnings announcement ( $\mathrm{I} / \mathrm{B} / \mathrm{E} / \mathrm{S}$ Daily Detail Tape), and the average of the last forecast from each individual analyst (I/B/E/S Daily Detail Tape) made after a company's fiscal yearend but before the annual earnings announcement, to determine the PMBAF and DISP measures. Each approach produced results that are qualitatively similar to the results reported. 


$$
\begin{aligned}
& \mathrm{DA}_{i t}=b_{0}+b_{1}\left(\mathrm{DISP}_{i t}\right)+b_{2}\left(\mathrm{PMBAF}_{i t}\right)+b_{3}\left(\mathrm{PMBAF}_{i t} * \mathrm{DISP}_{i t}\right) \\
& +b_{4}(\text { CASH_WGT } i t)+b_{5}\left(\text { LEVERAGE }_{i t}\right)+b_{6}\left(\text { LOGTA }_{i t}\right) \\
& +b_{7}\left(\mathrm{BIGSIX}_{i t}\right)+b_{8}\left(\mathrm{PY} \mathrm{DA}_{i t}\right)+b_{9}\left(\mathrm{NLUPP}_{i t}\right)+e_{i r} \text {, }
\end{aligned}
$$

where
$\mathrm{DA}_{i t} \quad=$ estimated discretionary accruals from eq. (2);
DISP $_{i t} \quad=$ measure of analysts' forecast dispersion (calculated in the last month), a summary forecast measure was available from $\mathrm{I} / \mathrm{B} / \mathrm{E} / \mathrm{S}$ before the annual earnings announcement;
PMBAF $_{i t}=$ this variable is coded $1(0)$ when premanaged earnings are below (above) the analysts' forecast;
CASH $\_W_{i t}=$ cash flow from operations scaled by the beginning of period total asset balance;
LEVERAGE $_{i t}=$ total debt divided by stockholders' equity;
LOGTA $_{i t}=$ the log of total assets;
BIGSIX $_{i t}=$ this variable is coded $1(0)$ if the company used a Big Six (or non-Big Six) auditor;
PY $\perp A_{i t}=$ the discretionary accrual from the prior year; and
NLUP $_{i t} \quad=$ this variable is coded $1(0)$ if the current year's premanaged earn- ings exceed the prior year's reported net income.

A significant negative association exists between operating cash flows and total accruals that influences the estimation of discretionary accruals (Shivakumar [1996]). To control for this influence on the measurement of discretionary accruals the variable CASH_WGT is incorporated in the model. Managers who are close to debt covenant violations have incentives to take income-increasing actions to defer or avoid the costs of a breach (Watts and Zimmerman [1986]; Healy and Palepu [1990]; DeFond and Jiambalvo [1994]) or to reduce earnings in the face of contractual negotiations (DeAngelo et al. [1994]). To control for the effects of debt on management's reporting decisions we use LEVERAGE as a control variable.

To control for firm size, which is considered a proxy for the amount of available information about a firm's financial position (Chaney and Jeter [1992]; Lobo and Mahmoud [1989]), we include the log of total assets (LOGTA) in the regression. The variable BIGSIX controls for the ability of Big Six auditors to constrain management's use of discretionary accruals (Becker et al. [1998]). Prior year discretionary accruals (PY_DA) are included to control for the reversing nature of accruals (Dechow [1994]). Finally, we include the variable NI_UP to capture company incentives related to prior period reported income (Burgstahler and Dichev [1997]).

Our predictions are as follows. The coefficient on PMBAF is expected to be positive, indicating managers' desire to reduce or eliminate negative analysts' forecast error (in support of $H_{1}$ ). A negative coefficient on DISP * PMBAF indicates that managers increase reported income as analysts' forecast dispersion lessens, when premanaged earnings are below analysts' forecasts (in support of $\mathrm{H}_{2}$ ). For firms with premanaged earnings above analysts' forecasts, conflicting managerial 
incentives preclude a definitive prediction for DISP (the influence of analysts' forecast dispersion on managers' use of discretionary accruals when premanaged earnings are above analysts' forecasts). A negative sign is expected on CASH_WGT due to the negative correlation between cash flows and accruals. LEVERAGE is consistently negative and LOGTA is consistently positive in prior applications of the cross-sectional Jones model (e.g., Becker et al. [1998]) and we have no reason to predict otherwise for our data. Big Six auditors reduce the use of discretionary accruals by management (Becker et al. [1998]) suggesting a negative sign on BIGSIX. The reversing nature of accruals will lead to a negative sign on PY_DA. The sign on NI_UP will be negative if managers use discretionary accruals to decrease reported income when prior year earnings levels have already been attained.

\subsection{Multivariate Results}

Table 3 presents the estimation results of Eq. (3). We report the predicted sign of the coefficients, the estimated coefficients and their significance level based on the White (1980) adjusted $t$ statistic, the adjusted $R^{2}$, and $F$ statistics for the model.

When premanaged earnings are below analysts' forecasts managers use income increasing discretionary accruals to increase reported earnings (PMBAF $=0.059$, $p<0.01$ ) when compared to firms with premanaged earnings above analysts' forecasts. This supports our prediction $\left(H_{1}\right)$ that when premanaged earnings are below analysts' forecasts, managers use discretionary accruals to increase reported earnings.

As analysts' dispersion decreases (DISP becomes smaller), managers consistently increase their use of income-increasing discretionary accruals (DISP = $-0.017, p<0.01, \mathrm{PMBAF} * \mathrm{DISP}=0.002, p>0.10$ ) irrespective of premanaged earnings levels. Collectively, these results indicate that managers consistently increase reported earnings when analysts are in agreement. This provides support for $\mathrm{H}_{2}$, but also indicates that when premanaged earnings are above analysts' forecasts, managers increase reported earnings in response to the decrease in analysts' forecast dispersion. The control variables are all significant, with the exception of PY_DA and are signed in the proper direction. ${ }^{14}$ Overall the evidence from our primary

14. An additional influence on management's utilization of discretionary accruals is the presence of a management forecast of earnings (Kasznik [1999]). To test the influence of management earnings forecasts on our results, we identified 800 sample firms that issued management earnings forecasts (4,055 sample firms did not issue management forecasts during this time period) for the years 19831987 (from the data set used in Baginski and Hassell [1997]). An analysis for this time period using eq. (3) while incorporating an indicator variable for the presence of a management forecast does not qualitatively affect our reported results. This demonstrates that the issuance of management forecasts does not significantly reduce the influence of the level and dispersion of analysts' forecasts on management's use of discretionary accruals. This is consistent with Sansing (1992), who shows that the presence of analysts' forecasts reduces the value relevance of management forecasts. While the Baginski and Hassell (1997) management forecast data do not allow comparison across our reported sample period, there is no reason to believe that the results for our time period would be qualitatively different. 
TABLE 3

Earnings Management Activity: OLS Regressions of Discretionary Accruals on Levels of Premanaged Accrual Earnings, Analysts' Forecast Dispersion, and Control Variables

\begin{tabular}{lcc}
\hline \multicolumn{1}{c}{ Predicted } & & \\
\hline Variable & Sign & Coefficient \\
\hline Intercept & $?$ & $-0.012^{* * *}$ \\
DISP $_{i t}$ & $?$ & $-0.017^{* * *}$ \\
PMBAF $_{i t}$ & + & $0.059^{* * *}$ \\
PMBAF $_{i t} *$ DISP $_{i t}$ & - & 0.002 \\
CASH_WGT $_{i t}$ & - & $-0.135^{* * *}$ \\
LEVERAGE $_{i t}$ & - & $-0.035^{* * *}$ \\
LOGTA $_{i t}$ & + & $0.003^{* * *}$ \\
BIGSIX $_{i t}$ & - & $-0.007^{* *}$ \\
PY_DA $_{i t}$ & - & 0.003 \\
NI_UP $_{i t}$ & - & $-0.013^{* * *}$ \\
$n$ & & 13,532 \\
$F$ value & & 925.41 \\
Pr $_{2}>F$ & & 0.0001 \\
$R$ & & 0.381
\end{tabular}

Note: Significant at $0.01\left({ }^{* *}\right), 0.05(* *)$, and $0.10\left(^{*}\right)$ using White's $t(1980)$.

Model:

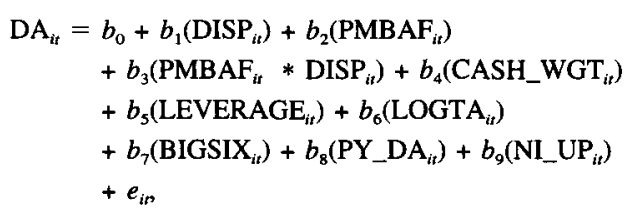

where

DA $_{i t} \quad=$ estimated discretionary accruals from Equation (2);

DISP $_{i t} \quad=$ measure of analysts' forecast dispersion (calculated in the last month), a summary forecast measure was available from $\mathrm{I} / \mathrm{B} / \mathrm{E} / \mathrm{S}$ before the annual earnings announcement;

PMBAF $_{i t}=$ this variable is coded $1(0)$ when premanaged earnings are below (above) the analysts' forecast;

CASH_WGT ${ }_{i t}=$ cash flow from operations scaled by the beginning of period total asset balance;

LEVERAGE $_{i t}=$ total debt divided by stockholders' equity;

LOGTA $_{i r}=$ the log of total assets;

BIGSIX $_{i t}=$ this variable is coded $1(0)$ if the company used a Big Six (or non-Big Six) auditor;

PY_DA $_{i t} \quad=$ discretionary accrual from the prior year;

NI_UP $_{i t}=$ this variable is coded $1(0)$ if the current year's premanaged earnings exceed the prior year's reported net income. 
analysis suggests that managers' discretionary financial reporting decisions are affected by the level and dispersion in analysts' forecasts.

\section{Supplemental Analyses}

To be consistent with the recent literature on the measurement of discretionary accruals we apply the cross-sectional version of the Jones model. Shivakumar (1996) shows that the cross-sectional version of the Jones model is biased for extreme levels of cash flows. Therefore, we control for the level of cash flows in our primary analysis. Dechow et al. (1995) find that the time-series version of the Jones model for estimating discretionary accruals is well specified in a random sample of firm-years, but that it is biased in samples with extreme financial performance. Discretionary accrual estimates tend to be biased upward for firms reporting unusually high earnings and biased downward for firms reporting unusually low earnings. We control for this potential bias (that might also affect the crosssectional estimation technique) by incorporating indicator variables representing firms with return on assets (ROA) in the upper and lower 10 percent of the entire sample of firms in an untabulated analysis. The results indicate an improved $R^{2}$ for our model of 0.449 (vs. 0.381 in Table 3 ) indicating that extreme levels of ROA help explain the variance in our measure of discretionary accruals. Importantly, the parameter estimates on the hypothesized and control variables are qualitatively similar to our reported results. This indicates that our results are not driven by the inclusion of firms with extreme financial performance. ${ }^{15}$

Another concern is that a selection bias in our portfolio formation (PMBAF $=1,0$ ) might be influencing our reported results. Specifically, discretionary accruals (measured with error) affect the portfolio assignments, and also serve as the dependent variable. McNichols and Wilson (1988) note that earnings management tests can produce biased results when the partitioning variable is correlated with the dependent variable. This design issue is also raised in Gaver et al. (1995), DeFond and Park (1997), and Lim and Lustgarten (1998).

The effects of this potential bias on our findings can be reduced if we partition the data using a measure of relative performance that is not mechanically related to our estimate of discretionary accruals. Such a partition would essentially be an "instrumental variable" that surrogates for premanaged earnings. An instrumental variable is a variable that is correlated with the variable of interest, but uncorrelated with the measurement error that may be present in the variable of interest. Because cash flows are expected to be correlated with performance but are measured independently of total accruals, they are not affected by the measurement error that results from the estimation of discretionary accruals. To test the sensitivity of our results to this potential bias, we replicate the analysis in Tables 2 and 3 using cash flows and lagged cash flows, by industry and year, as instruments to determine the

15. An additional analysis using the upper and lower 10 percent of EPS produces qualitatively similar results. 
predicted value on which to partition current performance. The results of this analysis (not reported) continue to support our predictions.

By controlling for the potential correlation between our partitioning variable (PMBAF) and the measurement error associated with our estimation of discretionary accruals, we have shown that our reported results are robust with respect to model specification and are not adversely influenced by the potential for correlation between the predicted discretionary accrual and the portfolio assignment. The significant results in the hypothesized direction, obtained with the instrumental variables analysis, indicate that our reported results are not solely determined by the potential negative correlation bias of the model. ${ }^{16}$

To ensure that within-firm dependencies are not significantly influencing our reported results we perform an analysis similar to Imhoff, Lipe, and Wright (1993). They note that using multiple observations for each firm could overstate the significance levels of pooled time-series cross-sectional tests. The use of intertemporal means of the variables for each firm avoids this concern. Our untabulated analysis indicates that the use of multiple observations per firm is not systematically overstating our significance levels on the hypothesized variables of interest. PMBAF and DISP remain significant at 0.01 and signed in the proper direction.

The previous analyses control for potential specification and measurement problems that may arise by using our measure of discretionary accruals to partition the data into firms below/above analysts' forecasts, the estimation of discretionary accruals, and the potential effects of within-firm dependencies. A more fundamental concern regarding the estimation process is raised in Dechow et al. (1997). Their analysis indicates that existing techniques for measuring earnings management (e.g., the Jones model) are likely to misclassify some nondiscretionary accruals as being discretionary, thereby overstating the magnitude of discretionary accruals. Guay et al. (1996) likewise fail to find conclusive evidence that the estimation of discretionary accruals is precise.

Since the use of discretionary accruals might be problematic, we perform additional analyses that do not rely on the estimation of discretionary accruals. Specifically, to avoid using discretionary accruals altogether we form scaled deviations of earnings from forecasts (reported EPS - mean analysts' forecasted EPS)/(assets per share) and create histograms. ${ }^{17}$ If $H_{1}$ is true, we expect to see more firms in the interval just above zero (because firms manage earnings to be equal to or just above forecasts). We expect to see fewer firms in the interval just below zero (firms that were within striking distance of the goal but chose not to achieve it). If earnings management exists, the histogram should have a sharp discontinuity around zero.

To test the significance of the hypothesized relationship between earnings man-

16. Additionally, we performed an analysis of eq. (3) without the PMBAF term. This eliminates the potential measurement error problems associated with our partitioning variable. This analysis also produces a significantly negative coefficient on DISP $(-0.013, p<0.001)$. Furthermore, the application of Shivakumar's (1996) discretionary accrual estimation technique that adjusts for differential levels of cash flows does not qualitatively affect our reported results.

17. Analyses using unscaled analysts' forecast error produced qualitatively similar results. 
agement and analysts' forecasts, we adapt the approach of Burgstahler and Dichev (1997) and construct a statistical test of the distribution of analysts' forecast errors. Consistent with Burgstahler and Dichev we avoid assumptions regarding the form of analysts' forecast error distribution. Therefore, under the null hypotheses of no earnings management, the cross-sectional distribution of analysts' forecast errors should be relatively smooth. The test statistic is the difference between the actual number of observations in the interval and the expected number of observations in the interval, divided by the estimated standard deviation of the difference. ${ }^{18}$

The expected number of observations in any interval is the average of the number of observations in the adjacent intervals (i.e., the expected number of observations in the interval immediately to the right of zero is the average of the number of observations in the interval to the immediate left of zero and the second interval to the right of zero). As noted by Burgstahler and Dichev (1997), the standardized differences in the intervals immediately to the left and right of zero will be simultaneously affected and are not independent; therefore, we will concentrate on the results for the interval immediately to the left of zero (for information purposes we report standardized differences to the right of zero in parentheses). If the hypothesized earnings management does not exist, the standardized differences should be distributed approximately normal with mean 0 and standard deviation 1 , and the number of firms in the intervals surrounding zero should not be significantly different from each other.

Figure 1 represents a histogram of the distribution of analysts' forecast errors scaled by total assets per share. Histogram interval widths are 0.0025 for the range of -0.05 to $+0.05 .^{19}$ The figure shows a sharply single-peaked distribution, with a substantial increase in observations directly to the right of zero. The standardized difference ( $Z$ statistic) for the interval immediately to the left of zero is $-9.73, p$ $<0.001$ (the standardized difference to the right of zero is $43.71, p<0.001$ ). This is consistent with earnings management designed to reach or slightly exceed analysts' forecast estimates. Visual inspection indicates a tight distribution around zero. This provides further confirmation that earnings are managed toward analysts' forecasts as indicated in our previous analysis. ${ }^{20}$

To investigate the influence of analysts' forecast dispersion on earnings management, we categorize the observations based on our measure of dispersion, DISP.

18. The number of observations in an interval is a random variable that is approximately independent of the number of adjacent intervals. Therefore, the variance of the difference between the observed and expected number of observations is approximately the sum of the variance of the components of the difference. Denoting the probability that an observation will fall into the interval $i$ by $p_{\mathrm{i}}$ and the total number of observations as $N$, the variance of the difference between the observed and expected number of observations for interval $i$ is approximately $N p_{i}\left(1-p_{i}\right)+1 / 4\left[N\left(p_{i-1}+p_{i+1}\right)(1\right.$ $\left.-p_{i-1}-p_{i+1}\right)$ ] (see Burgstahler and Dichev [1997]).

19. We use the same scale adopted by Burgstahler and Dichev (1997) to enable comparison of our results.

20. A similar analysis by Burgstahler and Dichev (1997) investigating earnings management to ensure an increase in reported net income over the prior period produced a markedly more disperse pattern of standardized differences. 
FIGURE 1

Distribution of Analysts' Forecast Error Scaled by Assets per Share for $-0.05<$ Analysts' Forecast Error $<0.05$ and Interval Width $=0.0025$

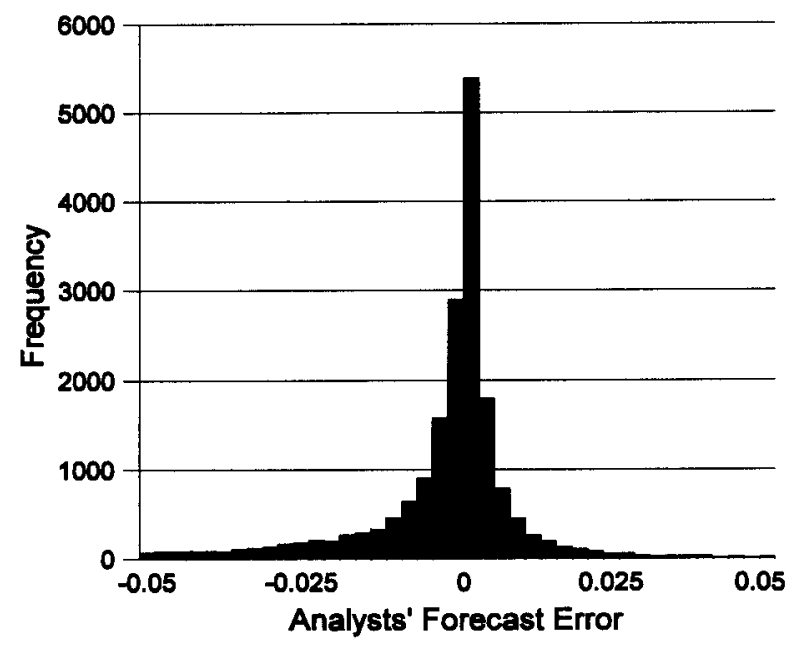

\begin{abstract}
Notes
The figure shows the empirical distribution of analysts' forecast error (reported earnings less analysts' mean earnings forecasts) scaled by total assets per share as of the beginning of the year. The distribution interval widths are 0.0025 . For example, the first interval to the right of zero contains all scaled analysts' forecast errors in the interval [0.0000, 0.0025], the second interval contains [0.0025, $0.0050]$, and so on. The vertical axis labeled frequency represents the number of observations in each interval.
\end{abstract}

Figure 2 shows the resulting distributions of analysts' forecast errors. Panels A and $B$ provide evidence of earnings management to achieve analysts' forecasts in the first $(Z=-11.98$ [41.37]) and second $(Z=-4.47$ [24.84]) quartiles. Visual inspection of panels A, B, C, and D clearly indicates that the magnitudes of standardized differences are shrinking as analysts' forecast dispersion increases. The fatter tails to the left of zero in panels $C$ and $D$ are consistent with firms potentially choosing a "big bath" reporting strategy in periods when earnings are low and there is greater uncertainty regarding expected earnings levels. These results demonstrate that managers prefer to present pleasant earnings "surprises" as opposed to earnings "disappointments," especially when analysts are in agreement regarding expected earnings.

A caveat to our reported results is that the desire to "meet or beat" analysts' forecasts can be achieved by ensuring that analysts' forecasts are equal to or below manager's expectations of future earnings by privately or publicly communicating 
FIGURE 2

Distribution of Analysts' Forecast Error Scaled by Assets per Share for $-0.05<$ Analysts' Forecast Error $<0.05$ and Interval Width $=0.0025$

Panel A

Forecast Dispersion in First Quartile

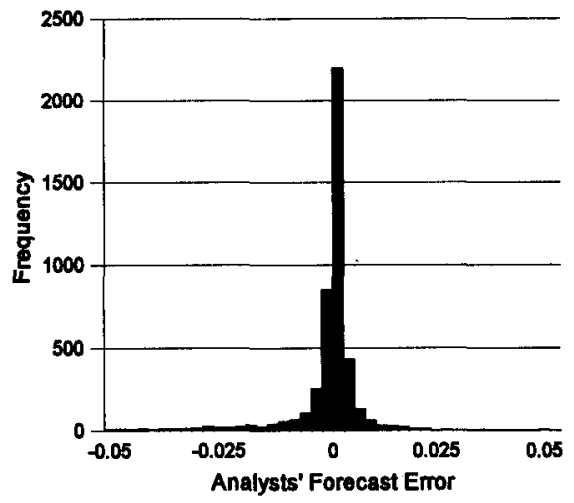

Panel C

Forecast Dispersion in Third

Quartile

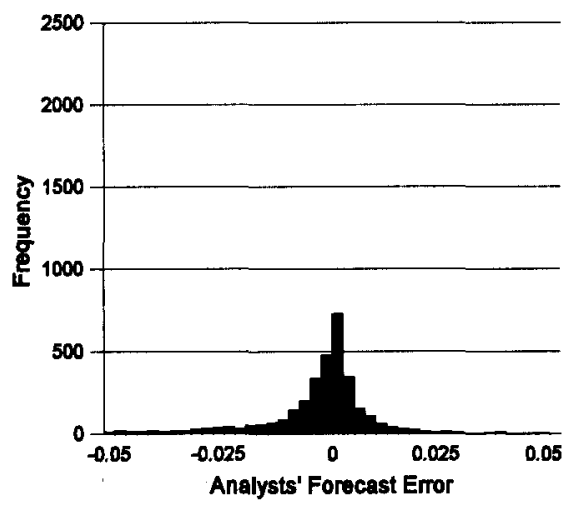

Panel B

Forecast Dispersion in Second Quartile

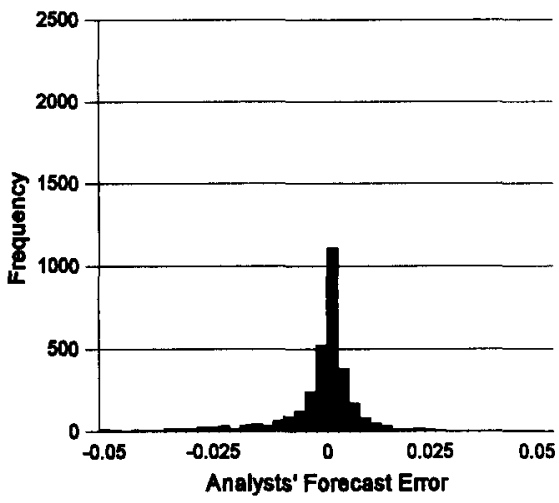

Panel D

Forecast Dispersion in Fourth Quartile

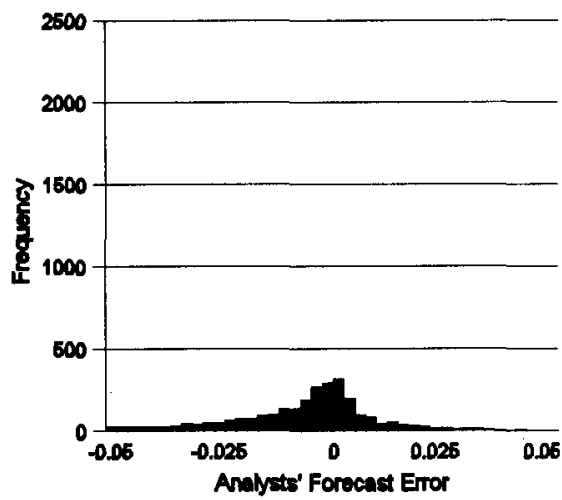

Notes

The figure shows four empirical distributions of analysts' forecast errors scaled by total assets per share, categorized according to analysts' forecast dispersion. Panel A (D) shows the distribution for firms with the lowest (highest) level of analysts' forecast dispersion. 
earnings estimates to analysts, ${ }^{21}$ by managing earnings to ensure that analysts' forecasts are met, or both. Therefore the results depicted in Figures 1 and 2 could be representative of the use of one or a combination of these techniques. Anecdotal evidence indicates that large changes in earnings expectations are easier to accomplish through ex ante adjustment of earnings expectations. Our results suggest that the use of discretionary accruals allow managers to "meet or beat" analysts' forecasts once they are set.

By controlling for the potential correlation problem with our partitioning method and the potential measurement error associated with our estimation of discretionary accruals, we demonstrate that our reported results are robust with respect to model specification and are not adversely influenced by our model's potential inability to accurately estimate nondiscretionary accruals.

\section{Conclusion}

SEC Chairman Levitt has expressed concerns about the use of earnings management to report earnings consistent with analysts' forecasts. By reducing earnings surprises, management attempts to increase stock price while developing a reputation for predictability and dependability thereby reducing investor, customer, and employee dissonance.

This study is the first to present empirical evidence of the effect of analysts' forecasts on earnings management. We hypothesize that managers have incentives to use their discretion over accounting accruals to eliminate negative earnings surprises. We predict that managers will move earnings toward analysts' forecasts when premanaged earnings are below market expectations. This prediction is supported. When premanaged earnings exceed analysts' forecasts, managers have conflicting incentives with respect to the use of discretionary accruals. On one hand, there is an incentive to "store up" discretionary accruals for future periods by employing income-decreasing accruals (thereby reducing analysts' forecast errors). Alternatively, there exists an incentive to preserve a positive earnings surprise in expectation of a favorable stock price reaction. We find evidence consistent with the incentive to "store up" discretionary accruals.

We are the first to investigate the degree to which ex ante earnings expectation beliefs, measured using analysts' forecast dispersion, affect management's use of discretionary accruals. We find that as the dispersion in analysts' earnings forecasts decreases, managers utilize discretionary accruals to increase reported earnings. This applies to settings where premanaged earnings are both below and above analysts' forecasts. Overall, our findings are consistent with the idea that managers

21. Matsumoto (1999) provides evidence that managers appear to influence analysts' forecasts before an earnings announcement to ensure that earnings estimates are met. Barron and Stuerke (1998) suggest disclosures made by management directly to analysts are possibly attempts to mitigate investor uncertainty after an earnings announcement. 
use discretionary accruals to align earnings with market expectations and increase income when the dispersion in analysts' forecasts is low.

Managers can use their discretion over reported accrual balances to improve the value relevance of reported earnings (e.g., Watts and Zimmerman [1986]) or they can use their discretion opportunistically. The latter is a specific concern of SEC Chairman Levitt since such practices reduce the quality of reported earnings. Lynn Turner, chief accountant of the SEC, notes that "One of the reasons US capital markets have been cited as the best in the world is the high quality and integrity of the financial reporting system in the United States' (SEC Chief Accountant's Letter to AICPA on Auditing and Financial Reporting Concerns, October 9,1998 ). Our research provides the initial insight into the influence of analysts' forecasts on earnings management and confirms Chairman Levitt's suspicion that this practice is effective and widespread. Future research regarding this relationship should address the specific accounting "gimmicks" (e.g., the abuse of "'materiality") noted by SEC Chairman Levitt in his speech at NYU's Center for Law and Business (September 28, 1998) and their influence on earnings management to achieve analysts' forecasts.

\section{REFERENCES}

Abarbanell, J. S., W. N. Lanen, and R. E. Verrecchia. 1995. “Analysts' Forecasts as Proxies for Investor Beliefs in Empirical Research." Journal of Accounting and Economics 20 (January): 31-60.

Ajinkya, B., R. Atiase, and M. Gift. 1991. "Volume of Trading and the Dispersion in Financial Analysts' Earnings Forecasts." The Accounting Review 66 (April): 389-401.

Ajinkya, B., and M. Gift. 1984. " CCorporate Managers Earnings Forecast and Symmetrical Adjustments of Market Expectations." Journal of Accounting Research 22 (Autumn): 425-444.

Atiase, R. K., and L. S. Bamber. 1994. "Trading Volume Reactions to Annual Accounting Earnings Announcements: The Incremental Role of Predisclosure Information Asymmetry." Journal of Accounting \& Economics 17 (May): 309-330.

Baginski, S. P., and J. M. Hassell. 1997. "Determinants of Management Forecast Precision." The Accounting Review 72 (April): 303-312.

Barron, O. E., and P. S. Stuerke. 1998. "Dispersion in Analysts' Earnings Forecasts as a Measure of Uncertainty.' Journal of Accounting, Auditing \& Finance 13 (Summer): 245-270.

Becker, C. L., M. L. DeFond, J. Jiambalvo, and K. R. Subramanyam. 1998. "The Effect of Audit Quality on Earnings Management." Contemporary Accounting Research 15 (Spring): 1-24.

Besley, D. A., E. Kuh, and R. E. Welsch. 1980. Regression Diagnostics. New York: John Wiley \& Sons.

Brown, L. D. 1993. "Earnings Forecasting Research: Its Implications for Capital Markets Research." International Journal of Forecasting 9 (November): 295-320.

Brown, L. D., and J. C. Han. 1992. "The Impact of Annual Earnings Announcements on Convergence of Beliefs."' The Accounting Review 67 (October): 862-876.

Burgstahler, D., and I. Dichev. 1997. "Earnings Management to Avoid Earnings Decreases and Losses." Journal of Accounting and Economics 24 (January): 99-126.

Chaney, P. K., and D. C. Jeter. 1992. "The Effect of Size on the Magnitude of Long-Window Earnings Response Coefficients." Contemporary Accounting Research 8 (Spring): 540-562.

Comiskey, E., R. Walking, and M. Weeks. 1987. "Dispersion of Expectations and Trading Volume." Journal of Business, Finance and Accounting 14 (Summer): 229-239.

DeAngelo, H., L. DeAngelo, and D. J. Skinner. 1994. "Accounting Choice in Troubled Companies."'Journal of Accounting and Economics 17 (January): 113-43.

Dechow, P. M. 1994. "Accounting Earnings and Cash Flows as Measures of Firm Performance: The Role of Accounting Accruals." Journal of Accounting \& Economics 18 (July): 3-43. 
Dechow, P. M., J. Sabino, and R. G. Sloan. 1997. "Implications of Nondiscretionary Accruals for Earnings Management and Market-Based Research.' Working paper. University of Pennsylvania.

Dechow, P. M., R. G. Sloan, and A. P. Sweeney. 1995. "Detecting Earnings Management." The Accounting Review 70 (April): 193-226.

DeFond, M., and J. Jiambalvo. 1994. "Debt Covenant Violation and Manipulation of Accruals." Journal of Accounting and Economics 17 (January): 145-176.

DeFond, M., and C. Park. 1997. "Smoothing Income in Anticipation of Future Earnings." Journal of Accounting and Economics 23 (September): 115-139.

DeFond, M., and K. R. Subramanyam. 1998. "Auditor Changes and Discretionary Accruals." Journal of Accounting and Economics 25 (January): 35-67.

Dowen, R. J., and W. S. Bauman. 1991. "Revisions in Corporate Earnings Forecast and Common Stock Returns." Financial Analysts Journal 47 (March-April): 86-90.

Elliott, J., and D. Philbrick. 1990. "Accounting Changes and Earnings Predictability." The Accounting Review 65 (January): 157-174.

Fama, E. F. 1980. "Agency Problems and the Theory of the Firm." Journal of Political Economy 88 (April): 288-307.

Fox, J. 1997. "Learn to Play the Earnings Game (and Wall Street Will Love You)." Fortune 135 (March): 76-80.

Francis, J., D. Philbrick, and K. Schipper. 1995. “Earnings Surprises and Litigation Risk.” Working paper. University of Chicago.

Gaver, J. J., K. M. Gaver, and J. R. Austin. 1995. "Additional Evidence on Bonus Plans and Income Management." Journal of Accounting and Economics 19 (February): 3-28.

Guay, W. R., S. P. Kothari, and R. L. Watts. 1996. "A Market-Based Evaluation of Discretionary Accrual Models." Journal of Accounting Research 34 (Supplement): 83-105.

Healy, P. M. 1985. "The Effect of Bonus Schemes on Accounting Decisions." Journal of Accounting and Economics 7 (April): 85-107.

Healy, P. M., and K. G. Palepu. 1990. "The Effectiveness of Accounting-Based Dividend Constraints." Journal of Accounting and Economics 13 (January): 97-123.

Hirst, D. E., L. Koonce, and P. J. Simko. 1995. “Investor Reactions to Financial Analysts' Research Reports." Journal of Accounting Research 33 (Autumn): 335-351.

Imhoff, E., R. Lipe, and D. Wright. 1993. "The Effects of Recognition Versus Disclosure on Shareholder Risk and Executive Compensation." Journal of Accounting, Auditing \& Finance 8 (Fall): 335-368.

Imhoff, E., and G. Lobo. 1992. "The Effect of Ex Ante Earnings Uncertainty on Earnings Response Coefficients." The Accounting Review 67 (April): 427-440.

Ip, Greg. 1997. "Investors Now Search for Predictable Earnings." Wall Street Journal (March 31): $\mathrm{C} 1, \mathrm{C} 2$.

Jones, J. 1991. “Earnings Management during Import Relief Investigations." Journal of Accounting Research 29 (Autumn): 193-228.

Kasznik, R. 1999. "On the Association between Voluntary Disclosure and Earnings Management." Journal of Accounting Research 37 (Spring): 57-81.

King, R., G. Pownall, and G. Waymire. 1990. "Expectations Adjustment via Timely Management Forecasts: Review, Synthesis, and Suggestions for Future Research." Journal of Accounting Literature 9:113-144.

Lees, F. A. 1981. "Public Disclosure of Corporate Earnings Forecasts." New York: Conference Board.

Levitt, A. L. Remarks by Chairman Arthur Levitt Securities and Exchange Commission, The "Numbers Game," NYU Center for Law and Business, New York, 28 September, 1998. <http:// www.sec.gov/news/speeches/spch220.txt>.

Lim, S. C., and S. Lustgarten. 1998. "Testing for Income Smoothing Using the Backing Out Method." Working paper. Baruch College.

Lipe, R. 1990. "The Relation between Stock Returns and Accounting Earnings Given Alternative Information." The Accounting Review 65 (January): 49-71.

Lobo, G. J., and A. W. Mahmoud. 1989. "Relationship between Differential Amounts of Prior Information and Security Return Variability." Joumal of Accounting Research 27 (Spring): 116130.

Matsumoto, D. A. 1999. “Management's Incentives to Guide Analysts' Forecasts." Working paper. Harvard University. 
McNichols, M., and P. Wilson. 1988. "Evidence of Earnings Management from the Provision for Bad Debts." Journal of Accounting Research 26 (Supplement): 1-31.

Neter, J., W. Wasserman, and M. H. Kutner. 1985. Applied Statistical Models. Homewood, Ill: Richard D. Irwin.

O'Brien, P. 1988. "Analysts' Forecast as Earnings Expectation." Journal of Accounting and Economics 10 (January): 53-74.

Perry, S. E., and T. H. Williams. 1994. "Earnings Management Preceding Management Buyout Offers." Journal of Accounting \& Economics 18 (September): 157-180.

Sansing, R. C. 1992. "Accounting and the Credibility of Management Forecasts." Contemporary Accounting Research 9 (Fall): 33-45.

Shivakumar, L. 1996. "Estimating Abnormal Accruals for Detection of Earnings Management." IFA working paper 241-1996. London Business School.

Skinner, D. J. 1994. "Why Firms Voluntarily Disclose Bad News." Journal of Accounting Research 32 (Spring): $38-60$.

Subramanyam, K. R. 1996. "The Pricing of Discretionary Accruals," Journal of Accounting and Economics 22 (August-December): 249-281.

Sweeney, A. 1994. "Debt Covenant Violations and Managers' Responses." Journal of Accounting and Economics 17 (May): 281-308.

Trueman, B. 1986. "Why Do Managers Voluntarily Release Earnings Forecasts?" Journal of Accounting and Economics 9:53-71.

Turner, L. E. 1998. SEC Chief Accountant's October 1998 Letter to AICPA on Auditing and Financial Reporting Concerns. 9 October. <www.aicpa.org $>$.

Wall Street Journal. 1997. (March 31): C1, C2.

Walther, B. R., and R. H. Willis. 1999. "Are Earnings Surprises Costly?" Working paper. Northwestern University and Duke University.

Watts, R. L., and J. L. Zimmerman. 1986. Positive Accounting Theory. Englewood Cliffs, N.J.: PrenticeHall.

White, H. 1980. "A Heteroscedasticity-Consistent Covariance Matrix and a Direct Test of Heteroscedasticity." Econometrica 48:817-838.

Wu, Y. W. 1997. "Management Buyouts and Earnings Management." Journal of Accounting, Auditing \& Finance 12 (Fall): 373-389. 